\section{Impaired functional and hemodynamic response to graded exercise testing and its recovery in patients with subclinical hyperthyroidism}

\author{
Capacidade funcional e hemodinâmica em esforço e na \\ recuperação de pacientes com hipertireoidismo subclínico
}

Patrícia dos Santos Vigário',2, Dhiãnah Santini de Oliveira Chachamovitz², Patrícia de Fátima dos Santos Teixeira ${ }^{2}$, Mauro Augusto dos Santos ${ }^{3}$, Fátima Palha de Oliveira', Mário Vaisman²

\begin{abstract}
Objective: To evaluate the functional and hemodynamic responses during exercise and its recovery in patients with subclinical hyperthyroidism (SCH). Subjects and methods: A cross-sectional study was carried out with 29 patients on TSH-suppressive therapy with levothyroxine for thyroid carcinoma and 35 euthyroid subjects. All volunteers underwent a cardiopulmonary exercise testing on a treadmill and functional and hemodynamic variables were measured during exercise and its recovery. Results: $\mathrm{SCH}$ patients showed impaired functional response to exercise, marked by lower values for oxygen consumption and exercise duration in addition to premature achievement of the anaerobic threshold. Heart-rate and blood pressure recovery immediately after exercise were slower among SCH patients when compared to euthyroid subjects. Conclusion: $\mathrm{SCH}$ is associated with impaired functional and hemodynamic responses during exercise and its recovery. Arq Bras Endocrinol Metab. 2011;55(3):203-12
\end{abstract}

Keywords

Hyperthyroidism; oxygen consumption; heart-rate; blood pressure

\section{RESUMO}

Objetivo: Avaliar a capacidade funcional e hemodinâmica em esforço e durante a recuperação em pacientes com hipertireoidismo subclínico $(\mathrm{SCH})$. Sujeitos e métodos: Foi realizado um estudo seccional em que participaram 29 pacientes em terapia supressiva de TSH com levotiroxina para carcinoma diferenciado de tireoide e 35 indivíduos sem doença tireoidiana. Todos foram submetidos a um teste cardiopulmonar de esforço em esteira, no qual foram medidas variáveis funcionais e hemodinâmicas durante o exercício e a recuperação. Resultados: Os pacientes apresentaram um comprometimento na capacidade funcional, evidenciado por menores valores de consumo de oxigênio e duração de exercício, além do alcance prematuro do limiar anaeróbio. Imediatamente após o exercício, os pacientes apresentaram uma curva mais lenta de recuperação da frequência cardíaca e da pressão arterial. Conclusão: O SCH está associado ao comprometimento na capacidade funcional e hemodinâmica em esforço e na recuperação. Arq Bras Endocrinol Metab. 2011;55(3):203-12

\section{Descritores}

Hipertireoidismo; consumo de oxigênio; frequência cardíaca; pressão arterial
${ }^{1}$ Laboratório de Fisiologia do Exercício - Labofise/ LErC, Escola de Educação Física e Desportos, Universidade Federal do Rio de Janeiro (UFRJ), Rio de Janeiro, RJ, Brazil ${ }^{2}$ Serviço de Endocrinologia, Hospital Universitário Clementino Fraga Filho, UFRJ, Rio de Janeiro, RJ, Brazil ${ }^{3}$ Instituto Nacional de Cardiologia - Ministério da Saúde, Rio de Janeiro, RJ, Brazil
Correspondence to: Patrícia dos Santos Vigário Av. Rainha Elizabeth, 637, ap. 701 22081-030 - Rio de Janeiro, RJ, Brazil

patriciavigario@yahoo.com.br

Received on Oct/19/2010 Accepted on Feb/18/2011

\section{INTRODUCTION}

$\mathrm{D}$ ifferentiated thyroid carcinoma is relatively rare in the general population, accounting for $1 \%$ of all cancers. It has an excellent prognosis, with long-term survival rates of $90 \%-95 \%(1)$. As part of the treatment, $\mathrm{TSH}$-suppressive therapy with levothyroxine $\left(\mathrm{LT}_{4}\right)$ is 
recommended in order to minimize the risk of disease recurrence (2). This kind of therapy accounts for the majority of subclinical hyperthyroidism $(\mathrm{SCH})$ cases in the general population. $\mathrm{SCH}$ is characterized by a serum thyrotropin (TSH) level below the lower limit of the reference range with normal free thyroxine $\left(\mathrm{FT}_{4}\right)$ and tri-iodothyronine $\left(\mathrm{T}_{3}\right)$ levels $(3)$.

Recent studies have shown that $\mathrm{SCH}$ has adverse effects on the cardiovascular system similar to those found in overt hyperthyroidism (4). The most common functional cardiac alterations include decreased diastolic function, enhanced left ventricular mass, elevated heart rate $(\mathrm{HR})$, and decreased exercise performance $(5,6)$. In addition, $\mathrm{SCH}$ is related to autonomic imbalance characterized by attenuated vagal activity and increased sympathetic activity $(7,8)$. All those manifestations, however, seem to be less severe in SCH patients when compared to those with overt hyperthyroidism (9).

Cardiopulmonary exercise testing (CPET) is a noninvasive and a cost-effective method that adds gas exchange measurements to an electrocardiogram and blood pressure analysis, conventionally assessed in ergometric tests. It evaluates the interaction between the cardiovascular system (heart and systemic circulation), pulmonary system (lungs and pulmonary circulation), and contractile muscles during exercise (10). Through measurements of expired fractions of oxygen and carbon dioxide, and ventilation flow during exercise, it is possible to evaluate the functional capacity, which is an important predictor of cardiovascular disease (11). The major advantage of the CPET is related to the fact that it is a direct measurement of functional capacity, in contrast to the conventional ergometric test which may overestimate functional capacity in about $20 \%$ (12).

Heart-rate (HR) response to exercise and its recovery is a complex physiologic process controlled by the autonomic nervous system (ANS). The increase in HR during exercise is due to activation of the sympathetic nervous system and inhibition of vagus nerve activity, while parasympathetic reactivation is related to HR recovery. An attenuated HR response to exercise, also called chronotropic incompetence, and a slow HR recovery after exercise reflect impairment of the ANS $(13,14)$. A study conducted in a large cohort of asymptomatic men revealed that those with a slower decrease in HR had a 2.1 times increased risk of sudden death from myocardial infarction in relation to the reference group. Also, the relative risk of sudden death from myocardial infarction was 6.18 in subjects with lower increase in HR from rest to peak of exercise (15).

In this scenario, it is evident that poor exercise tolerance (functional capacity), elevated resting heart-rate (HR), and inadequate HR and blood pressure responses to both exercise and its recovery contribute to an increased cardiovascular risk and all-cause mortality $(11,13,14)$.

Although functional and hemodynamic responses to exercise and its recovery have been studied in a variety of diseases, specially the cardiovascular diseases, regarding $\mathrm{SCH}$ patients, these two issues have not been evaluated together, so far. Thus, the aim of this study was to evaluate functional capacity and hemodynamic response during and immediately after cardiopulmonary exercise testing in patients with $\mathrm{SCH}$ on TSH-suppressive therapy with $\mathrm{LT}_{4}$ for differentiated thyroid carcinoma.

\section{SUBJECTS AND METHODS}

\section{Study and sample}

A cross-sectional study was conducted in $29 \mathrm{SCH}$ patients $\left(2\right.$ males) on TSH-suppressive therapy with $\mathrm{LT}_{4}$ for differentiated thyroid carcinoma for at least six months (with stable subclinical hyperthyroidism) prior to the beginning of the study. All volunteers were recruited from the Endocrine Clinic of the Hospital Universitário Clementino Fraga Filho, Universidade Federal do Rio de Janeiro, Brazil. SCH was defined as TSH

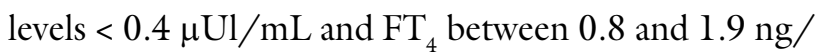
$\mathrm{dL}$. The inclusion criteria adopted for $\mathrm{SCH}$ patients were the following: age $\geq 18$ years, TSH serum levels < $0.4 \mathrm{mU} / \mathrm{L}$ (Immulite-DPC, Los Angeles, CA), FT 4 serum levels between 0.8 and $1.9 \mathrm{ng} / \mathrm{dL}$ (Immulite-DPC, Los Angeles, CA), $\mathrm{T}_{3}$ serum levels between 86.0 and $187.0 \mathrm{ng} / \mathrm{dL}$ (Immulite-DPC, Los Angeles, CA), absence of functioning thyroid tissue, and sedentary lifestyle for at least six months before the study. Active lifestyle was defined as the practice of aerobic physical activity for at least 30 minutes on five or more days a week or vigorous-intensity aerobic physical activity for at least 20 minutes on three or more days a week (16). The exclusion criteria were: positive whole body radioiodine scan, detectable serum thyroglobulin, overt hyperthyroidism, current smoker, cardiovascular or any chronic disease (even if treated), muscle and joint impairments that could limit the performance of the car- 
diopulmonary exercise testing, and use of medications that could affect the ANS.

A control group comprised of 35 euthyroid subjects $(5$ males $)>18$ years-old with $\mathrm{TSH}$ and $\mathrm{FT}_{4}$ serum levels within the reference range and no history of thyroid disease was also evaluated for the same parameters considered in the study. The same exclusion and inclusion criteria were adopted for this group, except for thyroid status.

In order to verify the impact of suppressive $\mathrm{LT}_{4}$ therapy, even in mildly suppressed patients, a subanalysis of $\mathrm{SCH}$ patients according to the last serum TSH measurement was performed: group $\mathrm{l}=\mathrm{TSH}<0.1 \mu \mathrm{UI} /$ $\mathrm{mL}(\mathrm{n}=17)$ and group $2=\mathrm{TSH} \geq 0.1 \mu \mathrm{UI} / \mathrm{mL}(\mathrm{n}=$ 12). The local Ethics Committee approved the study and written informed consent was obtained from $\mathrm{SCH}$ patients and euthyroid subjects.

\section{Study protocol}

SCH patients and euthyroid subjects underwent clinical evaluation with an endocrinologist. A structured review was conducted to gather data on thyroid disease history, symptoms, medication, coronary risk factors, health-related behaviors, and other clinical diagnoses. Serum TSH and FT4 were measured by immunometric assay (Immulite-DPC, Los Angeles, CA), with respective reference ranges of $0.4-4.0 \mu \mathrm{Ul} / \mathrm{mL}$ (sensitivity of $0.002 \mu \mathrm{Ul} / \mathrm{mL}$ ) and $0.8-1.9 \mathrm{ng} / \mathrm{dL}$ (sensitivity of $0.15 \mathrm{ng} / \mathrm{dL}$ ). In addition to the last serum TSH and FT4 measurements, which were considered in most statistical analysis, we also evaluated serum TSH over the last six months. After the written informed consent was obtained, SCH patients and euthyroid subjects were submitted to cardiopulmonary exercise testing at the Physical Education School of the same University.

\section{Cardiopulmonary exercise testing}

SCH patients and euthyroid subjects were submitted to cardiopulmonary exercise testing on a treadmill (constant velocity of $4.8 \mathrm{~km} / \mathrm{h}$ at a $3 \%$ grade increment during every 2 minutes) (17).

Electrocardiograms were continuously monitored at rest, during exercise, and during the first five minutes of exercise recovery. Blood pressure was checked at rest, every three minutes during the test, and in the first, third and fifth minutes of exercise recovery (mercury sphygmomanometer; Narcosul 1400-C). The following hemodynamic parameters were analyzed: a) $A t$ rest: heart-rate $\left(\mathrm{HR}_{\text {rest }} ;\right.$ bpm), systolic blood pressure $\left(\mathrm{SBP}_{\text {rest }} ; \mathrm{mmHg}\right)$, and diastolic blood pressure $\left(\mathrm{DBP}_{\text {rest }}\right.$; $\mathrm{mmHg})$; b) During exercise: peak heart-rate ( $\mathrm{HR}_{\text {peak }}$; bpm); peak systolic blood pressure $\left(\mathrm{SBP}_{\text {peak }} ; \mathrm{mmHg}\right)$; peak diastolic blood pressure $\left(\mathrm{DBP}_{\text {peak }} ; \mathrm{mmHg}\right)$; ratepressure product $(\mathrm{RPP}=\mathrm{HR} \times \mathrm{SBP} ; \mathrm{bpm} . \mathrm{mmHg})$, and median difference from exercise peak to resting for $\mathrm{HR}$, $\mathrm{SPB}$ and $\mathrm{DBP}\left(\Delta \mathrm{HR}_{\text {peak - rest }} ; \Delta \mathrm{SBP}_{\text {peak - rest }}\right.$, and $\Delta \mathrm{DBP}_{\text {peak }}$ -rest, respectively). Chronotropic incompetence was assessed in two ways: failure to achieve $85 \%$ of the target $\mathrm{HR}$ (220 - age) and failure to achieve $\geq 80 \%$ of the HR reserve $\left(\mathrm{CI}=\left(\mathrm{HR}_{\text {peak }}-\mathrm{HR}_{\text {rest }}\right) /\left((220\right.\right.$-age $\left.)-\mathrm{HR}_{\text {rest }}\right) \mathrm{x}$ 100). These last data were also called chronotropic index (18); c) Recovery immediately after exercise: HR in the first five minutes, median difference from $\mathrm{HR}_{\text {peak }}$ for every minute of recovery (a first-minute HR recovery < 12 bpm was considered abnormal) (19), SBP and DBP in the first, third and fifth minutes, and the median difference from $\mathrm{SBP}_{\text {peak }}$ and $\mathrm{DBP}_{\text {peak }}$ to the first, third and fifth minutes of recovery. SCH patients and euthyroid subjects performed an active recovery (velocity $=3.0$ $\mathrm{km} / \mathrm{h}$ at a $0 \%$ grade).

Respiratory gas exchange was sampled from a mouthpiece connected to a medium flow meter and a gas analyzer (Medical Graphics; VO2000). Ventilation flow, oxygen, and carbon dioxide expired fractions were measured breath-by-breath and recorded as the mean of three incursions. Before each test, the system was calibrated using a known fixed concentration of standard gases. The following parameters were considered at exercise peak: relative oxygen consumption $\left(\dot{V} \mathrm{O}_{2 \text { peak }}\right.$; defined as the highest value of $\dot{V} \mathrm{O}_{2}$ achieved at the end of exercise; $\mathrm{mL} / \mathrm{kg}$.min; STPD); relative carbon dioxide production $\left(\dot{V} \mathrm{CO}_{2 \text { peak }} ; \mathrm{mL} / \mathrm{kg} \cdot \mathrm{min}\right.$; STPD); minute ventilation ( $\left.\dot{V} \mathrm{E}_{\text {peak }} \mathrm{L} / \mathrm{min} ; \mathrm{STPD}\right) ; \mathrm{ex}-$ pired fraction of $\mathrm{O}_{2}$ and $\mathrm{CO}_{2}\left(\mathrm{Fe}_{\mathrm{O} 2 \text { peak }}\right.$ and $\mathrm{Fe}_{\mathrm{CO} 2 \text { peak }} ; \%$, respectively); oxygen pulse $\left(\dot{V} \mathrm{O}_{2} / \mathrm{HR} ; \mathrm{mL} / \mathrm{bpm}\right)$, and gas exchange ratio $\left(\mathrm{R}=\dot{V} \mathrm{CO}_{2} / \dot{V} \mathrm{O}_{2}\right)$. Exercise workload was analyzed considering total exercise duration in minutes (min:s) and the stage of the protocol $(\mathrm{km} / \mathrm{h}$ and \%). Anaerobic threshold (AT) was determined by analyzing the graph of ventilation equivalent for oxygen $\left(\dot{V} \mathrm{E}_{\mathrm{O} 2}=\dot{V} \mathrm{E} / \dot{V} \mathrm{O}_{2}\right) v s$. carbon dioxide $\left(\dot{V} \mathrm{E}_{\mathrm{CO} 2}=\right.$ $\dot{V} \mathrm{E} / \dot{V} \mathrm{CO}_{2}$ ) plotted during the exercise testing (20). AT is the point in which the $\dot{V} \mathrm{E} / \dot{V} \mathrm{O}_{2}$ graphic curve increases without a concomitant increase in $\dot{V} \mathrm{E} / \dot{V}$ $\mathrm{CO}_{2}(21)$.

The level of physical exertion during exercise was assessed using the Borg Exertion Perceived Scale, ran- 
ging from 6 (very easy) to 20 (maximum effort). SCH patients and euthyroid subjects were encouraged to reach symptom-limited maximal exercise.

The test was considered as maximal when one or more of the following parameters were obtained: Borg Exertion Perceived Scale $\geq 18$, a plateau of oxygen $\left(\dot{V} \mathrm{O}_{2 \max }\right), \mathrm{R} \geq 1.1$ and/ or maximum heart-rate. It is important to give evidence that the attainment of one or more of these parameters was not a criteria for test interruption. Test interruption criteria were: pectoris angina, SBP > $220 \mathrm{mmHg}$, DBP > $115 \mathrm{mmHg}$, dizziness, electrocardiogram signal alterations or physical manifestations of extreme fatigue.

All cardiopulmonary exercise testing measures were made by the same skilled professional, in a non-blinded manner in relation to thyroid status, but blinded concerning to TSH suppression level.

\section{Statistical analysis}

Continuous variables are presented as median and $25^{\text {th }}$ and $75^{\text {th }}$ percentiles, while categorical variables are presented as relative frequency, for descriptive analysis.

Distribution of the variables was assessed by the Kolmogorov-Smirnov test. As most of them presented nonparametric distribution and considering sample size, the comparison of continuous variables between SCH patients and euthyroid subjects was made by applying the Mann-Whitney U-test while categorical variables were compared by using Fisher's Exact test. The comparison of continuous variables among $\mathrm{SCH}$ patients with $\mathrm{TSH}<0.1 \mu \mathrm{UI} / \mathrm{mL}$, SCH patients with $\mathrm{TSH} \geq 0.1 \mu \mathrm{UI} / \mathrm{mL}$, and euthyroid subjects was made with the Kruskall-Wallis test and differences between two different subgroups were identified by applying the Mann-Whitney U-test.

Differences were statistically significant at $\mathrm{p}<0.05$ and all analyses were performed using the software SPSS 13.0 for Windows (SPSS Inc., Chicago, IL).

\section{RESULTS}

General characteristics of SCH patients and euthyroid subjects are shown in table 1 . SCH patients and euthyroid subjects were well-matched in respect to age, BMI, gender, and menopause status, which are potential confounding variables and thus, could interfere with the results. Median serum levels of the last TSH and $\mathrm{FT}_{4}$ measurements were significantly lower and higher, respectively, in $\mathrm{SCH}$ patients $(\mathrm{p}<0.05)$. The median disease duration was of $6.0(4.0-10.3)$ years. Evaluation of the two subgroups of SCH patients according to the grade of serum TSH suppression allows us to confirm that stable SCH occurred in the last six months, because mean serum TSH in that period was of $0.005(0.009-0.08) \mu \mathrm{UI} / \mathrm{mL}$ in the group of $\mathrm{pa}^{-}$ tients with last serum TSH measurement $<0.1 \mu \mathrm{UI} /$ $\mathrm{mL}$ and $0.16(0.12-0.40) \mu \mathrm{UI} / \mathrm{mL}$ in the group of patients with last serum TSH measurement $\geq 0.1 \mu \mathrm{UI} /$ $\mathrm{mL}$. Minimum and maximum serum levels of the last $\mathrm{FT}_{4}$ measurements were, respectively, 1.52 and 1.84 $\mathrm{ng} / \mathrm{dL}$ in the group of patients with last serum TSH < $0.1 \mu \mathrm{UI} / \mathrm{mL}$ and 1.19 and $1.81 \mathrm{ng} / \mathrm{dL}$ in the group of patients with last serum $\mathrm{TSH} \geq 0.1 \mu \mathrm{UI} / \mathrm{mL}$.

\section{Cardiopulmonary parameters}

SCH patients presented impaired functional capacity characterized by significantly reduced duration of exercise $(\mathrm{p}<0.01)$, exercise intensity $(\mathrm{p}<0.01)$ and median peak values of $\dot{V} \mathrm{E}(\mathrm{p}<0.0 \mathrm{l})$, relative $\dot{V} \mathrm{O}_{2}(\mathrm{p}<0.01)$, relative $\dot{V} \mathrm{CO}_{2}(\mathrm{p}<0.0 \mathrm{l})$, and $\dot{V} \mathrm{O}_{2} / \mathrm{HR}(\mathrm{p}=0.03)$ (Table 2). No differences were found in $\mathrm{R}, \mathrm{Fe}_{\text {O2peak }}$ and $\mathrm{Fe}_{\text {CO2peak }}$ between the groups, which means that $\mathrm{SCH}$ patients and euthyroid subjects achieved the same level of metabolic stress at the end of exercise. However, as $\mathrm{SCH}$ patients presented shorter duration of exercise, the end moment was achieved prematurely in this group.

Euthyroid subjects presented later AT achievement $(\mathrm{p}<0.01)$ (Table 2), with higher $\dot{V} \mathrm{O}_{2}[\mathrm{EU}=$ $19.4(16.0-24.3)$ vs. SCH $=16.1(14.6-17.6)$ $\mathrm{mL} / \mathrm{kg} . \mathrm{min} ; \mathrm{p}<0.0 \mathrm{l}]$, and $\dot{V} \mathrm{CO}_{2}[\mathrm{EU}=17.2(13.8$ - 22.4) vs. $\mathrm{SCH}=14.3(13.2-17.1) \mathrm{mL} / \mathrm{kg} \cdot \mathrm{min} ;$ $\mathrm{p}<0.01]$. The groups achieved AT with the same HR percentage in relation to $\mathrm{HR}_{\text {peak }}[\mathrm{SCH}=88.6(79.6$ - 94.2) vs. $\mathrm{EU}=85.5(75.4-93.0) \% ; \mathrm{p}=0.34]$, as well as the same $\dot{V} \mathrm{O}_{2}$ percentage in relation to $\dot{V}$ $\mathrm{O}_{2 \text { peak }}[\mathrm{SCH}=78.3(71.2-88.9)$ vs. $\mathrm{EU}=77.7$ (70.2 $-88.7) \% ; \mathrm{p}=0.71]$. The groups showed similar median values of $\mathrm{R}$ when the AT was achieved $[\mathrm{SCH}=$ $0.89(0.82-1.00) v s . \mathrm{EU}=0.90(0.84-0.99) \mathrm{mL} /$ kg.min; $\mathrm{p}=0.98$ ].

At peak of exercise, SCH patients and euthyroid subjects both presented the same median score on the Borg Scale (Table 2), indicating decreased exercise tolerance, i.e., premature fatigue in comparison to euthyroid subjects (considering that $\mathrm{SCH}$ patients achieved lower exercise intensity and duration). 
Table 1. Clinical and hormonal characteristics of SCH patients and euthyroid subjects

\begin{tabular}{|c|c|c|c|c|c|c|}
\hline Parameter & $\begin{array}{c}\text { SCH Patients } \\
(n=29)\end{array}$ & $\begin{array}{l}\text { SCH Patients TSH } \\
<0.1(n=17)\end{array}$ & $\begin{array}{l}\text { SCH Patients TSH } \\
\geq 0.1(n=12)\end{array}$ & $\begin{array}{l}\text { Euthyroid subjects } \\
\qquad(n=35)\end{array}$ & p-value ${ }^{\dagger}$ & p-value* \\
\hline Age (years) & $48.0(41.5-50.5)$ & $48.0(46.0-52.0)$ & $44.5(38.0-50.8)$ & $47.0(38.0-53.0)$ & 0.95 & 0.05 \\
\hline $\mathrm{BMI}\left(\mathrm{kg} / \mathrm{m}^{2}\right)$ & $26.4(22.0-30.6)$ & $23.0(22.1-29.1)$ & $27.1(22.2-33.2)$ & $26.9(23.3-29.8)$ & 0.57 & 0.69 \\
\hline Gender (male; \%) & 6.9 & 5.9 & 8.3 & 14.3 & 0.44 & 0.28 \\
\hline Menopause (yes; \%) & 29.6 & 35.3 & 16.6 & 37.1 & 0.60 & 0.68 \\
\hline Disease duration (years) & $6.0(4.0-10.3)$ & $6.0(4.0-14.0)$ & $6.5(3.8-9.5)$ & - & - & 0.77 \\
\hline TSH (last) $(\mu \mathrm{Ul} / \mathrm{mL})$ & $0.09(0.02-0.3)$ & $0.03(0.02-0.08)$ & $0.19(0.11-0.26)$ & $2.1(1.48-2.9)$ & 0.04 & $<0.01^{\#}$ \\
\hline $\mathrm{FT}_{4}(\mathrm{ng} / \mathrm{dL})$ & $1.7(1.5-1.8)$ & $1.7(1.7-1.8)$ & $1.6(1.4-1.8)$ & $1.2(1.1-1.2)$ & 0.04 & $<0.01^{\#}$ \\
\hline
\end{tabular}

Results are presented as median (25 $25^{\text {th }}$ and $75^{\text {th }}$ percentiles) for continuous variables and as relative frequency for categorical variables.

${ }^{\dagger}$ Mann-Whitney U-test for numeric variables and Fisher's Exact test for categorical variables; SCH patients vs. euthyroid subjects; statistical significance set at $p<0.05$.

* Kruskall-Wallis test for numeric variables and Fisher's Exact test for categorical variables; SCH patients TSH $<0.1$ vs. SCH patients TSH $\geq 0.1$ vs. euthyroid subjects; statistical significance set at $p<$ 0.05 . The differences were identified by the Mann-Whitney U-test.

"Mann-Whitney U-test; SCH patients TSH $<0.1 \neq$ SCH patients TSH $\geq 0.1 ; \mathrm{SCH}$ patients $\mathrm{TSH}<0.1$ = euthyroid subjects and $\mathrm{SCH}$ patients $\mathrm{TSH} \geq 0.1$ = euthyroid subjects; statistical significance set at $p<0.05$.

Table 2. Cardiopulmonary parameters of SCH patients and euthyroid subjects

\begin{tabular}{|c|c|c|c|c|c|c|}
\hline Parameter & $\begin{array}{l}\text { SCH Patients } \\
(n=29)\end{array}$ & $\begin{array}{l}\text { SCH Patients TSH } \\
<0.1(n=17)\end{array}$ & $\begin{array}{l}\text { SCH Patients TSH } \\
\geq 0.1(n=12)\end{array}$ & $\begin{array}{l}\text { Euthyroid Subjects } \\
\qquad(n=35)\end{array}$ & p-value ${ }^{\dagger}$ & p-value* \\
\hline$\dot{V} \mathrm{E}_{\text {peak }}(\mathrm{L} / \mathrm{min})$ & $33.4(28.1-41.2)$ & $31.8(25.0-40.7)$ & $34.5(30.3-43.6)$ & $46.0(37.2-54.2)$ & $<0.01$ & $<0.01^{\#}$ \\
\hline$\dot{V} O_{\text {2peak }}(\mathrm{mL} / \mathrm{kg} \cdot \mathrm{min})$ & $20.4(17.6-23.9)$ & $19.6(17.6-23.8)$ & $21.0(16.8-24.8)$ & $25.0(21.2-27.7)$ & $<0.01$ & $<0.01^{*}$ \\
\hline$\dot{V} \mathrm{CO}_{2 \text { peak }}(\mathrm{mL} / \mathrm{kg} \cdot \mathrm{min})$ & $19.4(17.2-22.9)$ & $18.7(16.5-22.5)$ & $19.3(17.9-22.7)$ & $25.5(19.4-28.7)$ & $<0.01$ & $<0.01^{*}$ \\
\hline$\dot{V} 0_{2} / H_{\text {peak }}\left(I . \mathrm{bpm}^{-1}\right)$ & $8.6(7.7-10.2)$ & $8.0(6.2-9.8)$ & $9.6(8.3-10.4)$ & $9.9(8.4-12.5)$ & 0.03 & $0.02^{\S}$ \\
\hline $\mathrm{Fe}_{02 \text { peak }}(\%)$ & $16.5(16.2-17.2)$ & $16.5(16.3-17.2)$ & $16.5(16.0-17.3)$ & $16.8(16.5-17.4)$ & 0.13 & 0.32 \\
\hline $\mathrm{Fe}_{\text {c02peak }}(\%)$ & $4.0(3.4-4.2)$ & $4.0(3.3-4.2)$ & $4.0(3.4-4.4)$ & $3.8(3.3-4.0)$ & 0.25 & 0.48 \\
\hline $\mathrm{R}_{\text {peak }}$ & $0.97(0.88-1.00)$ & $0.95(0.87-1.00)$ & $1.00(0.89-1.00)$ & $0.98(0.90-1.10)$ & 0.30 & 0.48 \\
\hline AT workload (min:s) & $5: 46(3: 44-7: 33)$ & $5: 14(3: 57-7: 18)$ & $5: 19(3: 24-7: 26)$ & $9: 11(7: 58-10: 27)$ & $<0.01$ & $<0.01^{*}$ \\
\hline AT exercise intensity (inclination; \%) & $7.5(3.0-9.0)$ & $6.0(3.8-9.0)$ & $7.5(3.0-9.0)$ & $12.0(11.3-15.0)$ & $<0.01$ & $<0.01^{*}$ \\
\hline Total workload (min:s) & $11: 32(8: 34-13: 04)$ & $11: 32(9: 03-13: 25)$ & $10: 30(8: 00-12: 36)$ & $14: 45(10: 44-16: 17)$ & $<0.01$ & $<0.01^{\#}$ \\
\hline Total exercise intensity (inclination; \%) & $15.0(12.0-18.0)$ & $15.0(12.0-18.0)$ & $15.0(12.0-18.0)$ & $21.0(15.0-24.0)$ & $<0.01$ & $<0.01^{*}$ \\
\hline Borg Scale & $19.0(16.0-19.0)$ & $19.0(15.0-19.0)$ & $19.0(17.5-19.8)$ & $19.0(17.0-19.0)$ & 0.70 & 0.25 \\
\hline
\end{tabular}

Results are presented as median (25 $5^{\text {th }}$ and $75^{\text {th }}$ percentiles).

${ }^{\dagger}$ Mann-Whitney U-test; SCH patients vs. euthyroid subjects; statistical significance set at $p<0.05$.

* Kruskall-Wallis test; $S C H$ patients TSH $<0.1$ vs. SCH patients TSH $\geq 0.1$ vs. euthyroid subjects; statistical significance for $p<0.05$. The differences were identified by the Mann-Whitney U-test.

"Mann-Whitney U-test; $S C H$ patients TSH $<0.1 \neq$ euthyroid subjects and SCH patients TSH $\geq 0.1 \neq$ euthyroid subjects; statistical significance set at $p<0.05$.

\& Mann-Whitney U-test; $S C H$ patients TSH $<0.1 \neq$ SCH patients TSH $\geq 0.1$ and SCH patients $\mathrm{TSH}<0.1$ ₹ euthyroid subjects; statistical significance set at $p<0.05$.

All cardiopulmonary differences between SCH patients and euthyroid subjects were maintained when the groups were compared considering TSH suppression levels (i.e., $\mathrm{TSH}<0.1 \mu \mathrm{Ul} / \mathrm{mL}$ and $\mathrm{TSH} \geq 0.1 \mu \mathrm{Ul} /$ $\mathrm{mL})$, except for $\dot{V} \mathrm{O}_{2} / \mathrm{HR}$ [SCH TSH $\geq 0.1=9.6(8.2$ $-10.4)$ vs. $\left.\mathrm{EU}=9.9(8.4-12.5) 1 . \mathrm{min}^{-1} ; \mathrm{p}=0.34\right]$.

\section{Hemodynamic parameters}

SCH patients and euthyroid subjects differed in all parameters related to $\mathrm{HR}$ (Table 3 ). The increase in $\mathrm{HR}$ from rest to peak of exercise ( $\mathrm{D} \mathrm{HR}_{\text {peak -rest }}$ ) was lower among $\mathrm{SCH}$ patients, since they presented higher HRrest $(\mathrm{p}=0.04)$ and lower $\mathrm{HR}_{\text {peak }}(\mathrm{p}=0.01)$. A total of
$31.0 \%$ of SCH patients did not reach $85 \%$ of the age-predicted maximum HR, $66.7 \%$ of which presented with $\mathrm{TSH}<0.1 \mu \mathrm{Ul} / \mathrm{mL}$. In euthyroid subjects, the ratio was of $5.7 \%(\mathrm{p}=0.02)$. Median chronotropic index in the $\mathrm{SCH}$ group was significantly lower $[\mathrm{SCH}$ $=0.79(0.65-0.95) v s . \mathrm{ES}=0.92(0.79-1.01) ; \mathrm{p}=$ 0.03 ] and under the predicted value (i. e., 0.80 ), which reflects an attenuated $\mathrm{HR}$ response to exercise.

The HR recovery response was slower among SCH patients during the first five minutes immediately after the peak of exercise (Table 3). However, considering TSH suppression levels, no statistical differences were found between $\mathrm{SCH}$ patients with $\mathrm{TSH} \geq 0.1 \mu \mathrm{Ul} / \mathrm{mL}$ and euthyroid subjects in the first three minutes. 
At the first minute of recovery, the $\mathrm{HR}_{\text {peak }}$ of all euthyroid subjects had decreased more than $12 \mathrm{bpm}$, while $17.2 \%$ of SCH patients (four patients of which showed $\mathrm{TSH}<0.1 \mu \mathrm{Ul} / \mathrm{mL}$ ) presented an abnormal $\mathrm{HR}_{\text {peak }}$ recovery, i.e., less than $12 \mathrm{bpm}$ in the same period.

Concerning blood pressure, no differences were found for both SBP and DBP at rest and at the peak of exercise between the two study groups (Table 4). The increase in SBP and DBP from rest to peak of exercise $\left(\mathrm{SBP}_{\text {peak - rest }}\right.$ and $\left.\mathrm{DBP}_{\text {peak - rest }}\right)$ was also similar between $\mathrm{SCH}$ patients and euthyroid subjects. During the first, third and fifth minutes of recovery, however, $\mathrm{SCH}$ patients presented a slower decrease of both SBP and DBP. Considering TSH suppression levels, no statistical differences were found between SCH patients with $\mathrm{TSH} \geq 0.1 \mu \mathrm{Ul} / \mathrm{mL}$, patients with $\mathrm{TSH}<0.1 \mu \mathrm{Ul} / \mathrm{mL}$ and euthyroid subjects in the first, third and fifth minutes of SBP recovery and in the first and third minutes of DBP recovery (Table 4 ).

Rate-pressure product $(\mathrm{RPP}=\mathrm{HR} \times \mathrm{SBP})$, which reflects cardiac work was similar between the groups even when considering TSH suppression levels.

Table 3. Heart rate parameters at rest, during exercise and recovery

\begin{tabular}{|c|c|c|c|c|c|c|}
\hline Parameter & $\begin{array}{c}\text { SCH Patients } \\
(n=29)\end{array}$ & $\begin{array}{c}\text { SCH Patients TSH }< \\
0.1(n=17)\end{array}$ & $\begin{array}{c}\text { SCH Patients TSH } \geq \\
0.1(n=12)\end{array}$ & $\begin{array}{l}\text { Euthyroid Subjects } \\
\qquad(n=35)\end{array}$ & p-value ${ }^{\dagger}$ & p-value* \\
\hline$H R_{\text {rest }}(b p m)$ & $88.0(76.0-96.0)$ & $86.0(75.0-98.0)$ & $89.0(76.5-94.8)$ & $79.0(60.0-90.0)$ & 0.04 & $0.03^{*}$ \\
\hline $\mathrm{HR}_{\text {peak }}(\mathrm{bpm})$ & $159.0(143.5-167.0)$ & $159.0(139.5-167.0)$ & $157.3(144.6-166.6)$ & $167.0(154.5-179.0)$ & 0.01 & $0.03^{*}$ \\
\hline$\Delta \mathrm{HR}_{\text {peak - rest }}(\mathrm{bpm})$ & $70.0(55.3-81.5)$ & $69.5(54.5-81.0)$ & $71.3(53.8-81.1)$ & $83.5(76.0-93.0)$ & $<0.01$ & $<0.01^{*}$ \\
\hline$\Delta \mathrm{HR}_{\text {peak - 1st min rec }}(\mathrm{bpm})$ & $20.0(14.3-25.6)$ & $18.0(12.0-25.5)$ & $23.2(14.2-28.0)$ & $23.5(19.5-33.0)$ & 0.03 & $0.04^{\S}$ \\
\hline$\Delta \mathrm{HR}_{\text {peak - 2nd min rec }}(\mathrm{bpm})$ & $35.3(24.6-42.8)$ & $35.3(21.3-39.6)$ & $36.0(24.6-43.8)$ & $41.0(33.5-49.0)$ & $<0.01$ & $0.04^{\S}$ \\
\hline$\Delta \mathrm{HR}_{\text {peak - 3rd min rec }}(\mathrm{bpm})$ & $40.5(30.0-44.8)$ & $38.5(29.8-43.6)$ & $42.3(27.0-50.0)$ & $48.0(40.5-55.5)$ & $<0.01$ & $<0.01^{\S}$ \\
\hline$\Delta \mathrm{HR}_{\text {peak - 4th min rec }}(\mathrm{bpm})$ & $42.0(30.0-49.0)$ & $41.3(30.4-48.1)$ & $42.5(26.0-51.0)$ & $50.0(45.5-58.0)$ & $<0.01$ & $<0.01^{\#}$ \\
\hline$\Delta \mathrm{HR}_{\text {peak - 5it min rec }}(\mathrm{bpm})$ & $45.0(34.0-48.5)$ & $45.0(34.8-47.0)$ & $42.5(26.5-53.5)$ & $53.5(46.0-60.0)$ & $<0.01$ & $<0.01^{*}$ \\
\hline
\end{tabular}

$\min =$ minute; $r$ rec = recovery.

Results are presented as median ( $25^{\text {th }}$ and $75^{\text {th }}$ percentiles).

† Mann-Whitney U-test; SCH patients vs. euthyroid subjects; statistical significance set at $p<0.05$.

* Kruskall-Wallis test; SCH patients TSH $<0.1$ vs. SCH patients TSH $\geq 0.1$ vs. euthyroid subjects; statistical significance set at $p<0.05$. The differences were identified by the Mann-Whitney U-test.

${ }^{*}$ Mann-Whitney U-test; SCH patients TSH $<0.1 \neq$ euthyroid subjects and SCH patients TSH $\geq 0.1 \neq$ euthyroid subjects; statistical significance set at $p<0.05$.

$\S$ Mann-Whitney U-test; SCH patients TSH $<0.1 \neq \mathrm{TSH} \geq 0.1$; SCH patients $\mathrm{TSH}<0.1 \neq$ euthyroid subjects; statistical significance set at $p<0.05$.

Table 4. Blood pressure parameters at rest, during exercise and recovery

\begin{tabular}{|c|c|c|c|c|c|c|}
\hline Parameter & $\begin{array}{l}\text { SCH Patients } \\
(n=29)\end{array}$ & $\begin{array}{l}\text { SCH Patients TSH } \\
<0.1(n=17)\end{array}$ & $\begin{array}{l}\text { SCH Patients TSH } \\
\geq 0.1(n=12)\end{array}$ & $\begin{array}{l}\text { Euthyroid Subjects } \\
\qquad(n=35)\end{array}$ & p-value ${ }^{\dagger}$ & p-value* \\
\hline $\mathrm{SBP}_{\text {rest }}(\mathrm{mmHg})$ & $130.0(120.0-140.0)$ & $130.0(120.0-140.0)$ & $125.0(112.5-141.5)$ & $120.0(110.0-130.0)$ & 0.20 & 0.34 \\
\hline $\mathrm{SBP}_{\text {peak }}(\mathrm{mmHg})$ & $182.0(166.0-200.0)$ & $180.0(170.0-200.0)$ & $197.0(162.5-200.0)$ & $170.0(158.0-200.0)$ & 0.28 & 0.34 \\
\hline$\Delta \mathrm{SBP}_{\text {peak - rest }}(\mathrm{mmHg})$ & $60.0(40.0-70.0)$ & $60.0(40.0-70.0)$ & $59.0(50.0-77.5)$ & $52.0(40.0-76.0)$ & 0.64 & 0.61 \\
\hline$\Delta S B P_{\text {peak - Ist min rec }}(\mathrm{mmHg})$ & $0.0(0.0-10.0)$ & $0.0(0.0-10.0)$ & $3.0(0.0-11.5)$ & $10.0(0.0-20.0)$ & 0.01 & 0.06 \\
\hline$\Delta \mathrm{SBP}_{\text {peak - 3rd min rec }}(\mathrm{mmHg})$ & $23.0(20.0-37.0)$ & $26.0(19.8-35.5)$ & $27.0(20.0-39.5)$ & $30.0(20.0-50.0)$ & 0.04 & 0.20 \\
\hline$\Delta S B P_{\text {peak - 5th min rec }}(m m H g)$ & $40.0(22.0-50.0)$ & $41.0(32.8-50.0)$ & $44.0(22.0-50.0)$ & $50.0(32.0-60.0)$ & 0.05 & 0.27 \\
\hline $\mathrm{DBP}_{\text {rest }}(\mathrm{mmHg})$ & $80.0(80.0-98.0)$ & $80.0(80.0-98.0)$ & $82.0(80.0-100.0)$ & $84.0(80.0-90.0)$ & 0.60 & 0.68 \\
\hline $\mathrm{DBP}_{\text {peak }}(\mathrm{mmHg})$ & $92.0(90.0-100.0)$ & $90.0(90.0-100.0)$ & $94.0(90.0-100.0)$ & $90.0(84.0-90.0)$ & 0.05 & 0.05 \\
\hline$\Delta \mathrm{DBP}_{\text {peak - rest }}(\mathrm{mmHg})$ & $10.0(0.0-13.0)$ & $10.0(0.0-18.0)$ & $10.0(5.0-13.5)$ & $8.0(4.0-10.0)$ & 0.64 & 0.72 \\
\hline$\Delta \mathrm{DBP} P_{\text {peak - 1st min rec }}(\mathrm{mmHg})$ & $0.0(0.0-1.0)$ & $0.0(0.0-0.0)$ & $0.0(0.0-1.5)$ & $4.0(0.0-10.0)$ & 0.03 & 0.06 \\
\hline$\Delta \mathrm{DBP}_{\text {peak - 3rd min rec }}(\mathrm{mmHg})$ & $7.0(0.0-10.0)$ & $8.0(0.0-10.0)$ & $6.0(0.0-10.0)$ & $10.0(4.0-12.0)$ & 0.07 & 0.21 \\
\hline$\Delta \mathrm{DBP} P_{\text {peak - 5h min rec }}(\mathrm{mmHg})$ & $10.0(2.0-10.0)$ & $10.0(3.0-10.0)$ & $10.0(2.0-14.0)$ & $12.0(10.0-20.0)$ & $<0.01$ & $0.01^{*}$ \\
\hline $\mathrm{DP}_{\text {peak }}(\mathrm{bpm} \cdot \mathrm{mmHg})$ & $\begin{array}{c}27540.0 \\
(23320.0-31255.0)\end{array}$ & $\begin{array}{c}27360.0 \\
(23120.0-30600.0)\end{array}$ & $\begin{array}{c}28425.0 \\
(25391.3-32185.0)\end{array}$ & $\begin{array}{c}26910.0 \\
(24240.0-32220.0)\end{array}$ & 0.63 & 0.64 \\
\hline
\end{tabular}

$\min =$ minute; rec = recovery.

Results are presented as median ( $25^{\text {th }}$ and $75^{\text {th }}$ percentiles).

${ }^{\dagger}$ Mann-Whitney U-test; SCH patients vs. euthyroid subjects; statistical significance set at $p<0.05$.

* Kruskall-Wallis test; $\mathrm{SCH}$ patients TSH $<0.1$ vs. SCH patients TSH $\geq 0.1$ vs. euthyroid subjects; statistical significance set at $p<0.05$. The differences were identified by the Mann-Whitney U-test.

*Mann-Whitney U-test; SCH patients TSH $<0.1 \neq$ euthyroid subjects and SCH patients TSH $\geq 0.1 \neq$ euthyroid subjects; statistical significance set at $p<0.05$. 


\section{DISCUSSION}

On this cross-sectional study, SCH patients on TSH-suppressive therapy with $\mathrm{LT}_{4}$ for thyroid carcinoma were evaluated for cardiopulmonary and hemodynamic function on exercise and its recovery. $\mathrm{SCH}$ was associated with impaired exercise capacity, characterized by premature achievement of anaerobic threshold, lower peak median values of $\dot{V} \mathrm{O}_{2}, \dot{V} \mathrm{CO}_{2}$ and $\dot{V} \mathrm{O}_{2} / \mathrm{HR}$, in addition to shorter duration of exercise for the same fatigue perception and metabolic stress level. These results mean that SCH patients had higher and premature anaerobic energy production to supplement aerobic energy production (which was deficient) when compared to euthyroid subjects, paired for gender, age, and menopause status. Such abnormalities (except for $\dot{V} \mathrm{O}_{2} / \mathrm{HR}$ ) were present in both patient subgroups (with a lesser and a higher degree of TSH suppression) in comparison to euthyroid subjects, indicating that the state of being $\mathrm{SCH}$, i.e., presenting serum TSH level below the lower limit of reference range with normal $\mathrm{FT}_{4}$ and $\mathrm{T}_{3}$ levels and not the level of TSH suppression is associated with cardiopulmonary impairments.

Thyroid hormones have relevant effects on the cardiovascular and ANS systems $(5,7,8)$. Overt hyperthyroidism is associated with alterations in cardiac function and structure such as left ventricular hypertrophy, increased systolic function, diastolic dysfunction, impaired exercise capacity, tachycardia and sympathovagal imbalance $(5,22)$. In $\mathrm{SCH}$, however, these manifestations are less clear. Some factors such as different etiologies of SCH (endogenous or exogenous), different duration of TSH-suppressive therapy with $\mathrm{LT}_{4}$ and the use of drugs that could interfere with the cardiovascular system, such as $\beta$-blockers, contribute to raise difficulties in the comparison of these studies.

During exercise, muscle bioenergetics is stressed while both the cardiovascular and pulmonary systems should respond to support the increased gas exchange requirements of the active muscle cells. So, a finely coordinated integration of these systems is necessary in order to permit muscle contractions $(11,21)$.

Maximal oxygen consumption $\left(\dot{V} \mathrm{O}_{2 \max }\right)$ is the most reliable variable to predict functional capacity of a subject. It represents the capacity of capitation (lungs), transport (heart and vessels), and use (muscles) of oxygen during exercise (10). It is obtained when a plateau of $\dot{V} \mathrm{O}_{2}$ is established, despite further increases in work rate. Usually, untrained and/or diseased people stop exercise testing before the achievement of this plateau $(21,23)$, as our study sample did. Because of this, $\dot{V} \mathrm{O}_{2 \text { peak }}$ was considered in the present analysis.

When metabolic demands of exercise begin to exceed oxygen delivery to working muscles, anaerobic metabolism ensues in order to supplement aerobic energy production $(20,21)$. Anaerobic threshold occurs at a higher percentage of $\dot{V} \mathrm{O}_{2 \max }$ or $\dot{V} \mathrm{O}_{2 \text { peak }}$ according to how much trained and/or healthy the subject is. Patients with impaired cardiovascular function have insufficient oxygen delivery to their active muscles at low work rates (11). Therefore, anaerobic threshold in these patients occurs at a low $\dot{V} \mathrm{O}_{2 \max }$ or $\dot{V} \mathrm{O}_{2 \text { peak }}$ or work rate.

Until this moment, only three studies in the literature have investigated the effect of SCH on functional capacity. Two groups have reported similar results to those shown in the present study. Mercuro and cols. (24) found significantly reduced exercise tolerance, $\dot{V} \mathrm{O}_{2 \text { peak }}$ and premature anaerobic threshold in 19 patients receiving long-term TSH-suppressive therapy with $\mathrm{LT}_{4}(5.7 \pm 3.5$ years $)$ at a fixed daily dose ranging from 1.8 to $4.0 \mu \mathrm{g} / \mathrm{kg}$. Such abnormalities, however, improved when $\mathrm{LT}_{4}$ therapy was individually tailored to the lowest dose required to keep serum TSH below reference range. In the same manner, Biondi and cols. (25) observed an impaired maximal exercise capacity, i.e., both reduced peak workload and exercise duration, in $\mathrm{SCH}$ patients on $\mathrm{TSH}$-suppressive therapy with $\mathrm{LT}_{4}$ for $5.0-9.0$ years who underwent a cycloergometer test. Conversely, in a previous study, our group did not find any abnormality in exercise performance of 14 SCH patients. Peak $\dot{V} \mathrm{O}_{2}, \dot{V} \mathrm{CO}_{2}$ and exercise duration were similar between $\mathrm{SCH}$ patients and healthy controls and the anaerobic threshold was achieved at the same percentage of peak $\dot{V} \mathrm{O}_{2}$. Their patients however, were younger than ours (median $=40.5$ years; interquartile range $=28.6-48.0)$ and they also presented lower median disease duration (3.0 years; interquartile range $=1.2-7.3)$. It may be hypothesized that age and time in TSH suppressive therapy may contribute to abnormalities in cardiopulmonary function in SCH (26).

The cardiovascular system is modulated by the ANS through sympathetic and parasympathetic stimulus. Basically, HR response to exercise may be described in three phases: a) initial tachycardia from rest to exercise (initial transient) which depends principally on a vagal withdrawal; b) rise in HR during progressive effort, which is associated to the combination of sympathetic 
activation and parasympathetic withdrawal; and c) fall in HR after cessation of exercise, which is a hall marker of the reactivation of the parasympathetic nervous system $(27,28)$. Autonomic imbalance, i.e., reduced vagal tone and increased sympathetic activity has been shown to be an independent risk factor of all-cause mortality even in patients without a history of heart disease (29).

In the present study, SCH patients presented signs of autonomic imbalance defined by three parameters: elevated resting $\mathrm{HR}$, abnormal $\mathrm{HR}$ response during exercise, and slower HR recovery immediately after exercise. Different from the findings observed in cardiopulmonary parameters, the level of TSH suppression seems to play an important role in determining these abnormalities, as they were predominantly present in patients with serum TSH $<0.1 \mu \mathrm{UI} / \mathrm{mL}$. Using different methods of analysis, Eustatia-Rutten and cols. (8) evaluated the autonomic nervous system of SCH patients on TSH-suppressive therapy with $\mathrm{LT}_{4}$. They found higher urinary excretion of catecholamines and lower heart rate variability among $\mathrm{SCH}$ patients, when compared to healthy subjects. Such characteristics were maintained even after six-months of restoration of euthyroidism. Petretta and cols. (9), evaluating time and frequency domain measures of heart-rate variability (24-h holter recordings) observed that SCH patients showed cardiac parasympathetic withdrawal compared to healthy controls, but such alteration was less severe when $\mathrm{SCH}$ patients were compared to patients with overt hyperthyroidism. In another study, nonelderly female SCH patients who were submitted to the tilt test with electrocardiographic record at rest, during espiratory sinus arrhythmia (RSA) maneuvers and after tilting, presented reduced vagal reserve at RSA maneuvers and blunted vagal response to sympathetic stimulus (7).

Among the different available noninvasive techniques for assessing the ANS, electrocardiogram analysis from rest to peak of exercise and its recovery can be easily incorporated in the clinical daily routine, in addition to its cost-effectiveness. It permits to evaluate $\mathrm{HR}$ response during different phases of exercise, each one with its prognostic value. Elevated resting HR, which was detected in the present study, is one of the most consistent abnormalities described in $\mathrm{SCH}(5,30)$. This abnormality has been proven to be associated with a higher risk of myocardial infarction and coronary deaths, even in healthy populations (14). Equally, abnormal HR recovery during the first minute after exercise reflects diminished vagal tone, which is also a strong predictor of cardiovascular risk and all-cause mortality. HR recovery immediately after exercise analysis, as a predictor of mortality, was first described by Cole and cols. (19). They followed 2.428 adults without pacemakers and without a history of heart failure or coronary revascularization for six years. The patients were encouraged to reach symptom-limited maximal exercise on a treadmill and after achieving peak workload all of them spent at least two minutes in an active cool-down period. An abnormal HR recovery was predictive of death in various subgroups, including the elderly and women, where higher prevalence of thyroid carcinoma is observed. In this investigation, abnormal HR recovery was present in $17.2 \%$ of SCH patients, most of them with TSH $<0.1 \mu \mathrm{Ul} / \mathrm{mL}$. Finally, electrocardiogram analysis allows identification of individuals with attenuated HR response to progressive effort, known as chronotropic incompetence. A two-year follow-up cohort study revealed that subjects who failed to reach $85 \%$ of their age-predicted maximum HR were more likely to die and, similarly, subjects who had a low chronotropic index had a higher death rate (18). In the Framingham Heart Study, a smaller increase in HR during exercise, the failure to achieve target HR and low chronotropic index were predictive of total mortality and coronary heart disease development (31). In the present study, SCH patients presented lower chronotropic index when compared to euthyroid subjects, in addition to a higher proportion of subjects who failed to achieve $85 \%$ of the target $\mathrm{HR}$, reinforcing that $\mathrm{SCH}$ patients, mainly those with $\mathrm{TSH}<0.1 \mathrm{mUl} / \mathrm{mL}$ compose a group with a higher risk of developing cardiovascular disease.

As for resting SBP and DBP, no differences were observed between $\mathrm{SCH}$ patients and euthyroid controls, which means that resting blood pressure is not affected by SCH. This finding is in accordance with two population-based surveys that showed that $\mathrm{SCH}$ is not associated with changes in blood pressure $(32,33)$. SCH also seems to be unassociated with peak blood pressure during exercise, since no differences were found in both SBP and DBP between SCH patients and euthyroid subjects, as reported by other studies $(24,26)$.

Immediately after exercise however, $\mathrm{SCH}$ presented a delayed SBP and DPB recovery compared to euthyroid subjects. Blood pressure is determined by an interplay between peripheral vascular resistance and cardiac output (heart-rate $\mathrm{x}$ stroke volume) and the ANS plays an important role in its modulation during exercise and at rest (34). Smith and cols. (35) demons- 
trated that the increase of sympathetic activity occurs in parallel with the increase of blood pressure. It was observed that normotensive subjects with elevated blood pressure presented higher sympathetic activity compared to normotensive subjects with normal blood pressure. In hypertensive patients, sympathetic activity exacerbation contributes to the increase and maintenance of blood pressure (35). The increased sympathetic activity observed in this study, demonstrated by elevated resting heart-rate and slower HR recovery after exercise compared to euthyroid subjects may explain the slower decline in SBP and DBP.

Major limitations to the present study were the small number of participants and the cross-sectional design. The first limitation may be consequence of the rigid inclusion and exclusion criteria which, however, these criteria generated homogeneous baseline characteristics and permitted the comparability between different studied groups. Moreover, the selection of $\mathrm{SCH}$ patients from $\mathrm{LT}_{4}$ suppressive therapy determined a homogeneous duration time of established disease, different from what generally happens with patients with endogenous SCH. Finally, all cardiopulmonary exercise testing measures were made in a non-blinded manner when comparing euthyroid subjects with $\mathrm{SCH}$ patients. This last limitation did not influence the comparisons according to the two subgroups of $\mathrm{SCH}$ patients because both the patients and skilled professionals who performed the cardiopulmonary tests were blinded in respect to serum TSH determinations.

In summary, the main results of this study were that SCH patients on TSH-suppressive therapy with $\mathrm{LT}_{4}$ for thyroid carcinoma had impaired functional and hemodynamic response to graded exercise testing. This was demonstrated by premature achievement of anaerobic threshold, lower peak values of $\dot{V} \mathrm{O}_{2}, \dot{V} \mathrm{CO}_{2}$, and $\dot{V} \mathrm{O}_{2} /$ $\mathrm{HR}$, elevated $\mathrm{HR}_{\text {rest }}$, chronotropic incompetence, and attenuated HR and blood pressure recovery immediately after exercise. The level of TSH suppression seems to play an important role in determining heart-rate abnormalities, different to what was seen with cardiopulmonary variables, where no differences were found between the subgroups of SCH patients, according to TSH suppression.

Early diagnosis is important to select the most appropriate intervention method. That may include use of beta-blockers and the adjustment of $\mathrm{LT}_{4}$ doses, besides non-pharmacological strategies, such as physical activity which has been proven to enhance physical fitness and reduce HR (36). All these actions taken together will contribute to a better patient-perceived health status and quality of life.

Acknowledgements: This study was supported by research grants from the National Council of Technological and Scientific Development $(\mathrm{CNPq})$.

Disclosure: no potential conflict of interest relevant to this article was reported.

\section{REFERENCES}

1. Sclumberger MJ, Torlantano M. Papillary and follicular thyroid carcinoma. Baillieres Best Pract Res Clin Endocrinolol Metab. 2000;14:601-13.

2. Maia AL, Ward LS, Carvalho GA, Graf H, Maciel RM, Maciel LM, et al. Thyroid nodules and differentiated thyroid cancer: Brazilian consensus. Arq Bras Endocrinol Metabol. 2007;51(5):867-93.

3. Biondi B, Palmieri EA, Klain M, Schlumberger M, Filetti S, Lombardi G. Subclinical hyperthyroidism: clinical features and treatment options. Eur J Endocrinol. 2005;152(1):1-9.

4. Biondi B, Cooper DS. The clinical significance of subclinical thyroid dysfunction. Endocr Rev. 2008;29(1):76-131.

5. Fazio S, Palmieri EA, Lombardi G, Biondi B. Effects of thyroid hormone on the cardiovascular system. Recent Prog Horm Res. 2004;59:31-50.

6. Abdulrahman RM, Delgado V, Ng AC, Ewe SH, Bertini M, Holman $E R$, et al. Abnormal cardiac contractility in long-term exogenous subclinical hyperthyroid patients as demonstrated by two-dimensional echocardiography speckle tracking imaging. Eur J Endocrinol. 2010;163(3):435-41.

7. Portella RB, Pedrosa RC, Coeli CM, Buescu A, Vaisman M. Altered cardiovascular vagal responses in nonelderly female patients with subclinical hyperthyroidism and no apparent cardiovascular disease. Clin Endocrinol (Oxf). 2007;67(2):290-4.

8. Eustatia-Rutten CF, Corssmit EP, Heemstra KA, Smit JW, Schoemaker RC, Romijn JA, et al. Autonomic nervous system function in chronic exogenous subclinical thyrotoxicosis and the effect of restoring euthyroidism. J Clin Endocrinol Metab. 2008;93(7):2835-41.

9. Petretta M, Bonaduce D, Spinelli L, Vicario ML, Nuzzo V, Marciano F, et al. Cardiovascular haemodynamics and cardiac autonomic control in patients with subclinical and overt hyperthyroidism. Eur $\mathrm{J}$ Endocrinol. 2001;145(6):691-6.

10. Sue DY, Wasserman K. Impact of integrative cardiopulmonary exercise testing on clinical decision making. Chest. 1991;99(4):981-92.

11. Wasserman K. Diagnosing cardiovascular and lung pathophysiology from exercise gas exchange. Chest. 1997;112(4):1091-101.

12. Peterson MJ, Pieper CF, Morey MC. Accuracy of VO2(max) prediction equations in older adults. Med Sci Sports Exerc. 2003;35(1):145-9.

13. Lauer MS. Chronotropic incompetence: ready for prime time. J Am Coll Cardiol. 2004;44(2):431-2.

14. Lauer MS. Autonomic function and prognosis. Cleve Clin J Med. 2009;76(Suppl 2):S18-22.

15. Jouven X, Empana JP, Schwartz PJ, Desnos M, Courbon D, Ducimetière $P$. Heart-rate profile during exercise as a predictor of sudden death. N Engl J Med. 2005;352(19): 1951-58.

16. Haskell WL, Lee I, Pate RR, Powell KE, Blair SN, Franklin BA, et al. Physical activity and public health: updated recommendation 
for adults from the American College of Sports Medicine and the American Heart Association. Med Sci Sport Exerc. 2007; 39(8):1423-34.

17. Mainenti MRM, Teixeira PFS, Oliveira FP, Vaisman M. Impacto do hipotireoidismo subclínico na resposta cárdio-pulmonar em esforço e na recuperação. Arq Bras Endocrinol Metab. 2007;51(9):1485-92.

18. Lauer MS, Francis GS, Okin PM, Pashkow FJ, Snader CE, Marwick TH. Impaired chronotropic response to exercise stress testing as a predictor of mortality. JAMA. 1999;10(281):524-29.

19. Cole CR, Blackstone EH, Pashkow FJ, Snader CE, Lauer MS. Heart-rate recovery immediately after exercise as a predictor of mortality. N Engl J Med. 1999;28:341(18):1351-7.

20. Gassi ER, Bankoff AD. Anaerobic threshold determination through ventilatory and electromyographics parameters. Electromyogr Clin Neurophysiol. 2010;50(3-4):131-5.

21. Wasserman K, Hansen J, Sue DY, Whipp BJ. Principles of Exercise Testing and Interpretation. Philadelphia: Lea \& Febiger; 1987.

22. Chen JL, Chiu HW, Tseng YJ, Chu WC. Hyperthyroidism is characterized by both increased sympathetic and decreased vagal modulation of heart rate: evidence from spectral analysis of heart rate variability. Clin Endocrinol (Oxf). 2006;64(6):611-6.

23. Albouaini K, Egred M, Alahmar A, Wright DJ. Cardiopulmonary exercise testing and its application. Heart. 2007;83(985):675-82.

24. Mercuro G, Panzuto MG, Bina A, Leo M, Cabula R, Petrini L, et al. Cardiac function, physical exercise capacity, and quality of life during long-term thyrotropin-suppressive therapy with levothyroxine: effect of individual dose tailoring. J Clin Endocrinol Metab. 2000;85(1):159-64.

25. Biondi B, Fazio S, Cuocolo A, Sabatini D, Nicolai E, Lombardi G, et al. Impaired cardiac reserve and exercise capacity in patients receiving long-term thyrotropin suppressive therapy with levothyroxine. J Clin Endocrinol Metab. 1996;81(12):4224-8.

26. Portella RB, Silva JLC, Wagmen MB, Oliveira FP, Buescu A, Vaisman $M$. Exercise performance in young and middle-aged female patients with subclinical hyperthyroidism. Thyroid. 2006;16(8):731-5.

27. $\mathrm{Ng} \mathrm{J}$, Sundaram S, Kadish AH, Goldberger JJ. Autonomic effects on the spectral analysis of heart rate variability after exercise. Am J Physiol Heart Circ Physiol. 2009;297(4):H1421-8.

28. Imai K, Sato H, Hori M, Kusuoka H, Ozaki H, Yokoyama H, et al. Vagally mediated heart rate recovery after exercise is accelerated in athletes but blunted in patients with chronic heart failure. J Am Coll Cardiol. 1994;24:1529-35.

29. Watanabe J, Thamilarasan M, Blackstone EH, Thomas JD, Lauer MS. Heart rate recovery immediately after treadmill exercise and left ventricular systolic dysfunction as predictors of mortality. The case of stress echocardiography. Circulation. 2001;104:1911-16.

30. Batrinos ML. The problem of exogenous subclinical hyperthyroidism. Hormones (Athens). 2006;5(2):119-25.

31. Lauer MS, Okin PM, Larson MG, Evans JC, Levy D. Impaired heart rate response to graded exercise. Prognostic implications of chronotropic incompetence in the Framingham Heart Study. Circulation. 1996;93(8):1520-6.

32. Völzke H, Alte D, Dörr M, Wallaschofski H, John U, Felix SB, et al. The association between subclinical hyperthyroidism and blood pressure in a population-based study. J Hypertens. 2006;24(10):1947-53.

33. Völzke H, Ittermann T, Schmidt CO, Dörr M, John U, Wallaschofski $\mathrm{H}$, et al. Subclinical hyperthyroidism and blood pressure in a population-based prospective cohort study. Eur J Endocrinol. 2009;161(4):615-21.

34. McHam SA, MarwickTH, Pashkow FJ, Lauer MS. Delayed systolic blood pressure recovery after graded exercise: an independent correlate of angiographic coronary disease. J Am Coll Cardiol. 1999;34(3):754-9.

35. Smith PA, Graham LN, Mackintosh AF, Stoker JB, Mary DA. Relationship between central sympathetic activity and stages of human hypertension. Am J Hypertens. 2004;17(3):217-22.

36. Almeida MB, Araújo CGS. Efeitos do treinamento aeróbico sobre a freqüência cardíaca Rev Bras Med Esporte. 2003;9(2):104-12. 